\title{
Trends of Rainfall and Temperature over North-Eastern Nigeria (1949-2014)
}

\author{
Soltan F. Hassan ${ }^{1}$, Attia M. El-Tantawi², Usman S. Hashidu ${ }^{3}$ \\ ${ }^{1}$ Prof. of Economic Geography, Institute of African Research and Studies, Cairo University \\ ${ }^{2}$ Prof. of Climatology, Institute of African Research and Studies, Cairo University, Egypt \\ ${ }^{1}$ Lecturer of Climatology, Geography Department, UMYU-Katsina, Nigeria
}

\begin{abstract}
Climate change has the propensity to alter rainfall and temperature regimes across the world, including Nigeria. This paper investigated the trends of rainfall and temperature in northeastern parts of Nigeria, based on data obtained from Nigeria Meteorological Agency for the period of 66 years (1949-2014). The Statistical techniques used for analysis are Mann-Kendall's test for trend, descriptive statistics, time-series plots and correlation analysis. The analyses performed involve the use of XLSTAT 2016 and Excel 2007. Results show a decreasing trend in annual total rainfall over both a long-term period (1949-2014) and a first short-term period (1949-1981), while a positive trend for the second short-term period (1982-2014) has been observed. The temperature on the other hand, showed an increasing trend over all the 3 periods especially the long-term period (1949-2014) which shows positive trends ranging from $0.04{ }^{\circ} \mathrm{C} /$ decade at Ibi to $0.09{ }^{\circ} \mathrm{C} /$ decade at Bauchi, with high level of significance at 0.001. Therefore, it concludes that temperature has increased over long and short periods while rainfall has increased only in the most recent period (1982-2014).
\end{abstract}

Keywords: Trend, Rainfall, Temperature, Climate change, Mann-Kendall test, Nigeria.

\section{Introduction}

There is always a change in climate condition over time period since the formation of earth's surface conditions. Past changes engrave on the landscape, have influenced all forms of life evolution, and were a subtext of our social and economic history (Burroughs, 2007). Many variables such as rainfall, temperature, humidity, atmospheric pressure, albedo, constitute weather and climate. Climate is defined as the average weather of a particular place over a long period of time. It is the statistical description in terms of the mean and variability of pertinent quantities for a period ranging from months to thousands or millions of years (IPCC, 2008). Warming of the climate system is unambiguous, and there are extraordinary observed changes over decades since the 1950s. There is a rise in sea level, warming of atmosphere and ocean, diminish in ice and snow as well as an increase in greenhouse gas concentrations (IPCC, 2013). Since the industrial revolution there is a steady increase in greenhouse gas emissions, which is the major cause of climate change by man. The rate of emissions is on steady increase over time and the earth's climate system computer models (natural and human) are not able to simulate recent warming without anthropogenic causes been included.

Abdussalam, (2015) used climatic records from 6 locations in northwest Nigeria to examine changes in indices of daily temperature and rainfall extremes for the period 1971-2010. It revealed that there has been significant increase in days that are warm and significant decreases in days that are cold. The increasing trends in the days that are warm are much stronger than the decreases in the number of cold days. On the other hand, there is an increase (though not significant) in total precipitation with only Kaduna showing otherwise. Today, due to increase in emission of greenhouse gases (Chlorofluorocarbons, Methane, Carbon dioxide and Nitrous oxide) into the atmosphere there is an evidence of rising global temperatures.

Large scale climatic disturbances can be triggered due to increased global warming, which ultimately may have meaningful influence on rainfall in the Sahel (Biasutti and Giannini, 2006). Trend detection in temperature and rainfall time series is one of the interesting research areas in climatology. Rainfall and temperature changes are not same. Variations can be much larger from region to region, and considerable spatio-temporal variations may exist between regions with different climate (Yue and Hashino, 2003). A number of studies have evaluated the trends in temperature and rainfall on different spatial and temporal scales in Nigeria (Ewona and Udo, 2008; Olofintoye and Sule, 2010; Abaje et al., 2012; El-Tantawi, 2013; Akinsanola et al., 2014; Bose, et al., 2015; El-Tantawi, 2016). Most of the researches carried out do not cover long periods and do not cover many meteorological stations. Hence, this study aimed at evaluating the trends of rainfall and temperature patterns in northeastern Nigeria. 


\section{Study Area}

The area is located between latitude $6^{\circ} 26^{\prime}-13^{\circ} 45^{\prime} \mathrm{N}$ and longitude $8^{\circ} 42^{\prime}-14^{\circ} 39^{\prime} \mathrm{E}$. It comprises of Borno, Yobe, Bauchi, Gombe, Adamawa and Taraba states (figure 1). It covers an area of 262,578 $\mathrm{Km}^{2}$ and has a population of $18,984,299$ persons according to 2006 Nigerian population census. It is characterized by relatively high temperatures throughout the year with the annual average varying from $28.32{ }^{\circ} \mathrm{C}$ in Yola to 25.92 ${ }^{\circ} \mathrm{C}$ in Bauchi while rainfall ranges between $467 \mathrm{~mm}$ at Nguru to $1091 \mathrm{~mm}$ at Ibi.

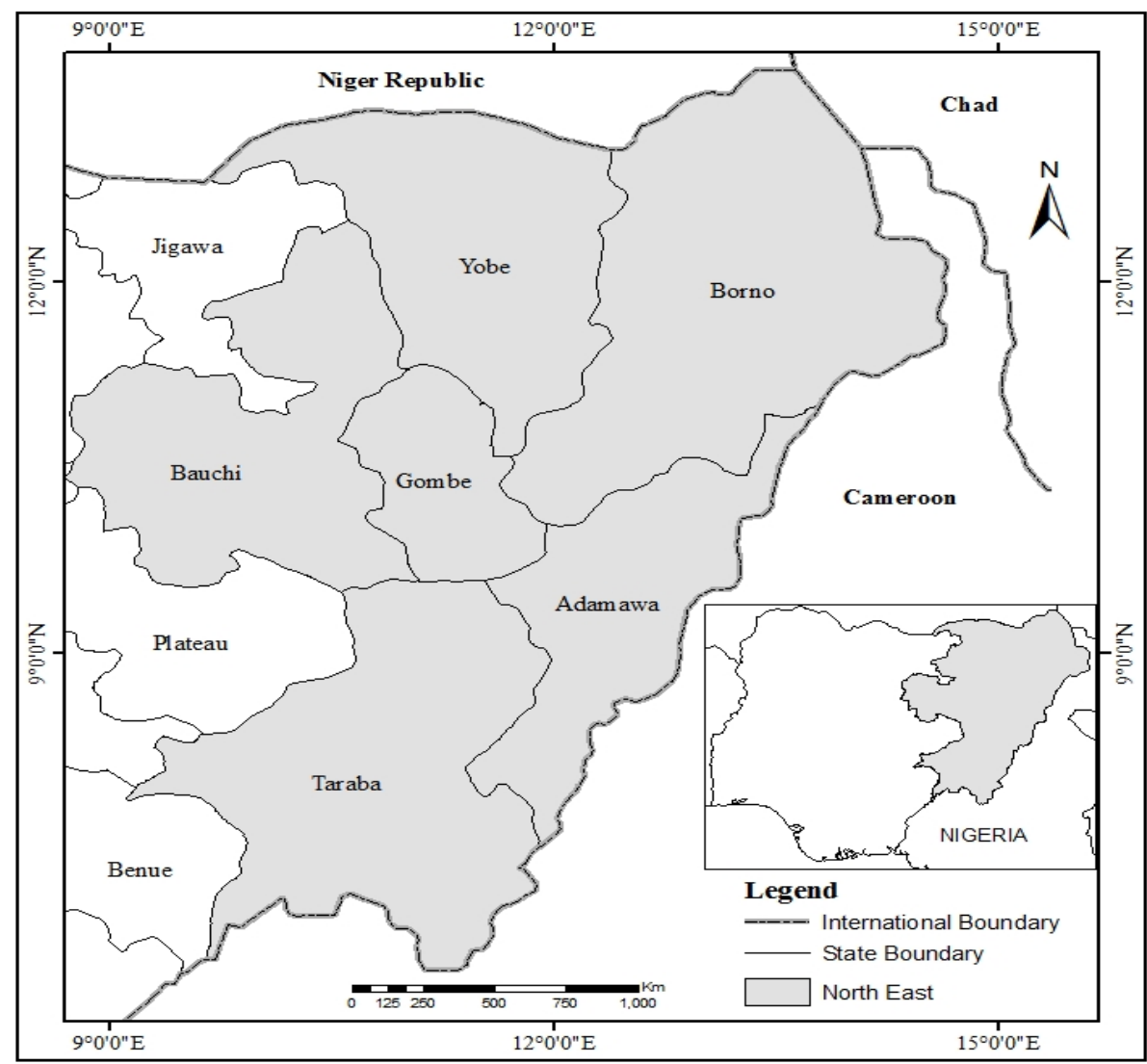

Figure 1: location of the study area

\section{Data and Methods}

Data of rainfall and temperature for the period 1949-2014 at six meteorological stations across northeastern parts of Nigeria were obtained from Nigerian meteorological agency (NIMET) (table 1). Spatial distribution of selecting stations was a criterion taken into consideration. A simple linear regression analysis, Known as the least square method or linear regression was used to detect trends in climatic data over a period time at all the stations under study, because trend is the basic tool for describing and analyzing the changes of climate parameters (Houghton, et al., 2001, El-Tantawi, 2005). The non-parametric Mann-Kendall test is applied. This test detects monotonic trends in series of environmental data, climate data or hydrological data (El-Tantawi 2005, Bose et al., 2015). A trend test based on a trend-to-noise ratio (total trend/standard deviation) was used for noticing linear or nonlinear trends (a T/N ratio >1.96), that is twice of its standard deviation, can be considered as a significant trend at a $95 \%$ level of confidence, lower ratios express a less significant level of confidence (Domroes, 1996).

Table 1: Stations under study, their location and elevation

\begin{tabular}{|l|l|l|l|}
\hline Station & Latitude & Longitude & Elevation \\
\hline Bauchi & 10.28 & 9.82 & 609 \\
\hline Ibi & 8.18 & 9.75 & 111 \\
\hline Maiduguri & 11.85 & 13.08 & 354 \\
\hline Nguru & 12.88 & 10.47 & 344 \\
\hline Potiskum & 11.70 & 11.03 & 488 \\
\hline Yola & 9.23 & 12.47 & 186 \\
\hline
\end{tabular}

Data source: NIMET, 2015 


\section{Results And Discussion}

Table 2 shows the descriptive statistics for mean annual rainfall over the study area. The mean annual rainfall ranges between 1091.19 at Ibi to 466.78 at Nguru; this could be due to latitudinal location as Nguru is the most northerly station while Ibi is the most southerly station. The highest standard deviation is at Bauchi while the lowest is at Yola. The coefficient of variation (CV) is latitude dependent decreasing from higher latitudes (in the north) to lower latitudes (in the south).

Table 2: Descriptive statistics of mean annual rainfall of northeastern Nigeria (1949-2014)

\begin{tabular}{|l|l|l|l|l|l|l|}
\hline Station & Observations & Minimum & Maximum & Mean & Std. deviation & CV (\%) \\
\hline Bauchi & 66 & 725 & 1999 & 1075 & 230 & 22 \\
\hline Ibi & 66 & 718 & 1569 & 1091 & 186 & 17 \\
\hline Maiduguri & 66 & 263 & 1076 & 613 & 151 & 25 \\
\hline Nguru & 66 & 226 & 758 & 466 & 128 & 28 \\
\hline Potiskum & 66 & 271 & 1054 & 692 & 180 & 26 \\
\hline Yola & 66 & 468 & 1326 & 884 & 133 & 15 \\
\hline
\end{tabular}

Data source: NIMET, 2015

Table 3: Descriptive statistics of mean annual temperature of northeastern Nigeria (1949-2014)

\begin{tabular}{|l|l|l|l|l|l|l|}
\hline Station & Observations & Minimum & Maximum & Mean & Std. deviation & CV $(\%)$ \\
\hline Bauchi & 66 & 25 & 27 & 26 & 0.64 & 2.5 \\
\hline Ibi & 66 & 27 & 29 & 28 & 0.38 & 1.4 \\
\hline Maiduguri & 66 & 26 & 29 & 28 & 0.54 & 2.0 \\
\hline Nguru & 66 & 26 & 29 & 28 & 0.64 & 2.3 \\
\hline Potiskum & 66 & 25 & 28 & 27 & 0.65 & 2.4 \\
\hline Yola & 66 & 27 & 30 & 28 & 0.61 & 2.2 \\
\hline
\end{tabular}

Data source: NIMET, 2015

The descriptive statistics of mean annual temperature as seen in table 3. Mean temperature ranges between 25.9 at Bauchi and 28.3 at Yola. Ibi has the lowest standard deviation with 0.38 while Potiskum has the highest with 0.65 . Bauchi has the highest $\mathrm{CV}$ of 2.5 while Ibi, which is the most southerly station, has the lowest CV of $1.4 \%$.

\section{Temporal Rainfall Trends}

It has been observed from the analysis that the annual total rainfall in the study area was changed over the long-term period of 66 years. The statistical analysis showed changes of rainfall at all stations under study over the long-term period 1949-2014 and over both short-term periods 1949-1981 and 1982-2014.

\section{Long-term trends 1949-2014}

Table 4: Annual rainfall trends/decade (mm), Mann-Kendall test for trend (Test $\mathrm{Z}$ ) and trend-noise ratios in northeastern Nigeria, 1949-2014

\begin{tabular}{|l|l|l|l|l|l|}
\hline Station & Mean & Trend/decade & T/Noise & Test Z & Significance \\
\hline Bauchi & 1075 & 0.02 & 0.001 & 1.94 & + \\
\hline Ibi & 1091 & -0.02 & -0.001 & -1.45 & \\
\hline Maiduguri & 613 & -0.02 & -0.001 & -1.63 & \\
\hline Nguru & 466 & -0.04 & -0.002 & -2.79 & $* *$ \\
\hline Potiskum & 692 & -0.02 & -0.001 & -1.70 & + \\
\hline Yola & 884 & -0.02 & -0.001 & -1.56 & \\
\hline
\end{tabular}

Data source: NIMET, 2015

$\mathrm{T} /$ Noise $=$ Trend-to-noise-ratio; values $>1.96$ indicate a linear trend

$\mathrm{Z}$ value $=\mathrm{A}$ positive (negative) value indicates an upward (downward) trend

Significance $=$ the tested levels of significance are $0.001,0.01,0.05$ and 0.1 as:

$* * *=0.001$ significance level. $\quad * *=0.01$ significance level. $\quad *=0.05$ significance level.

$+=0.1$ significance level. If the cell is blank, the level of significance is $>0.1$

The result in table 4 shows that negative trends existed at all stations except at Bauchi that has a trend of $0.02 \mathrm{~mm} /$ decade. The negative trends ranges between -0.02 to $-0.04 \mathrm{~mm} /$ decade. The test of significance shows that Nguru is highly significant at 0.01 while Bauchi and Potiskum were weakly significant at 0.1 , all the trends were not linear due to the high inter-annual variability (Figure 2). On the other hand, Ibi, Maiduguri and Yola were not significant. This result shows that rainfall in northeastern Nigeria has decreased especially at Nguru that is the most northerly station in the study area. 


\section{Short-term trends 1949-1981}

The trends for the short-term period (1949-1981) were negative at all stations except at Bauchi, it was no trend (table 5). The trends ranged between $-0.1 \mathrm{~mm} /$ decade at Ibi to $-0.04 \mathrm{~mm} /$ decade at Potiskum, the results of significance test shows that only Nguru and Potiskum were significant at 0.01 and 0.05 respectively. The results of trend-to-noise ratio shows that none of the stations has a linear trend due to high inter-annual variability (figure 2).

Table 5: Annual rainfall trends/decade (mm), Mann-Kendall test for trend (Test $\mathrm{Z}$ ) and trend-noise ratios in northeastern Nigeria, 1949-1981

\begin{tabular}{|l|l|l|l|l|l|}
\hline Station & Mean & Trend/decade & T/Noise & Test Z & Significance \\
\hline Bauchi & 1040 & 0.00 & 0.000 & 0.02 & \\
\hline Ibi & 1121 & -0.01 & 0.000 & -0.54 & \\
\hline Maiduguri & 648 & -0.03 & -0.001 & -1.46 & \\
\hline Nguru & 515 & -0.05 & -0.003 & -2.77 & $* *$ \\
\hline Potiskum & 726 & -0.04 & -0.001 & -2.22 & $*$ \\
\hline Yola & 911 & 0.00 & 0.000 & -0.02 & \\
\hline
\end{tabular}

Data source: NIMET, 2015.

See explanation in table 4

\section{Short-term trends 1982-2014}

The results of the trend analysis showed that all stations under study have positive trends except Yola that has a trend of $-0.03 \mathrm{~mm} /$ decade. The trends ranged between 0.01 at Ibi to $0.08 \mathrm{~mm} / \mathrm{decade}$ at Bauchi (table 6). The test of significance revealed that Bauchi and Nguru were highly significant at 0.001 while Maiduguri is significant at 0.01 level of significance, Ibi Potiskum and Yola were not significant.
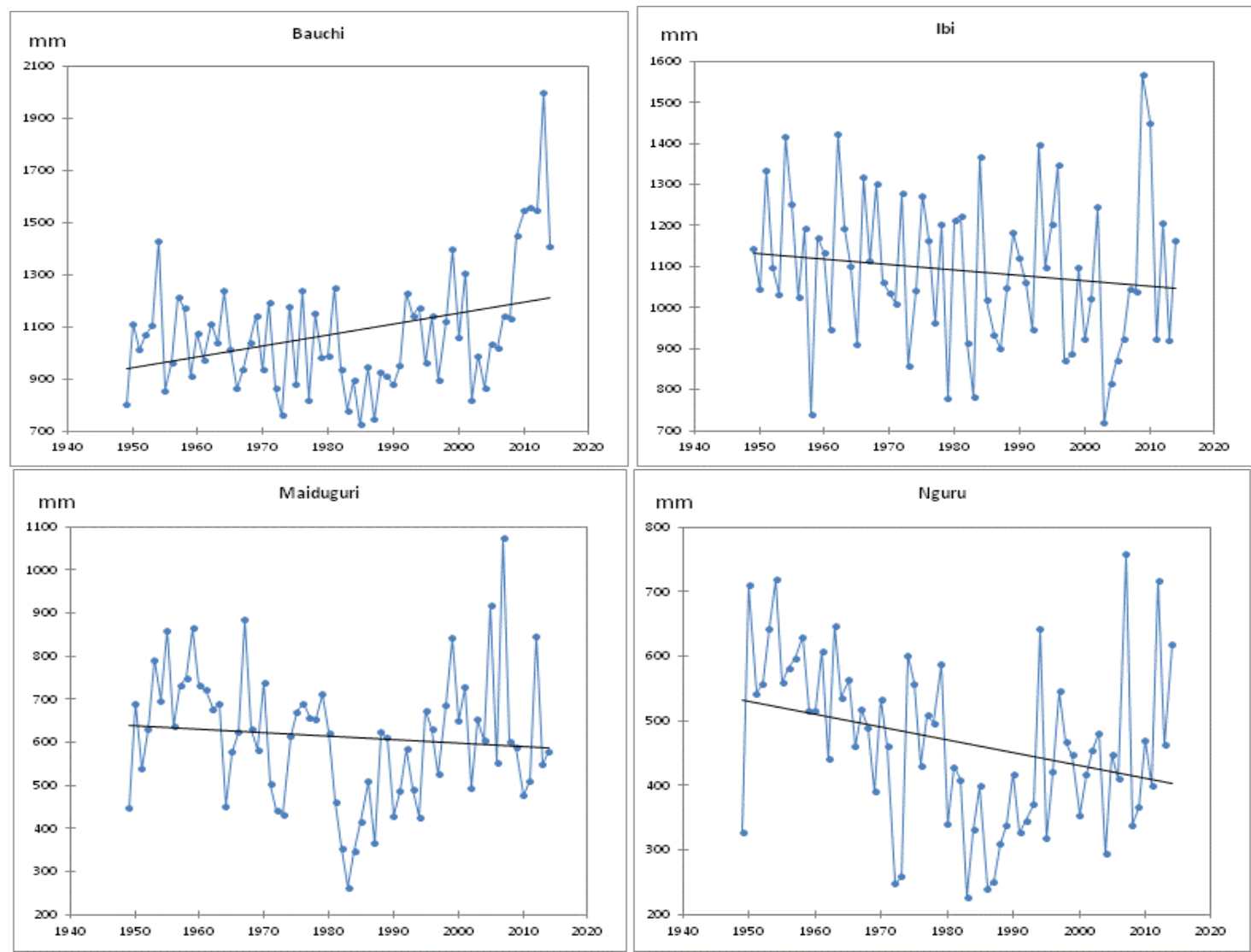

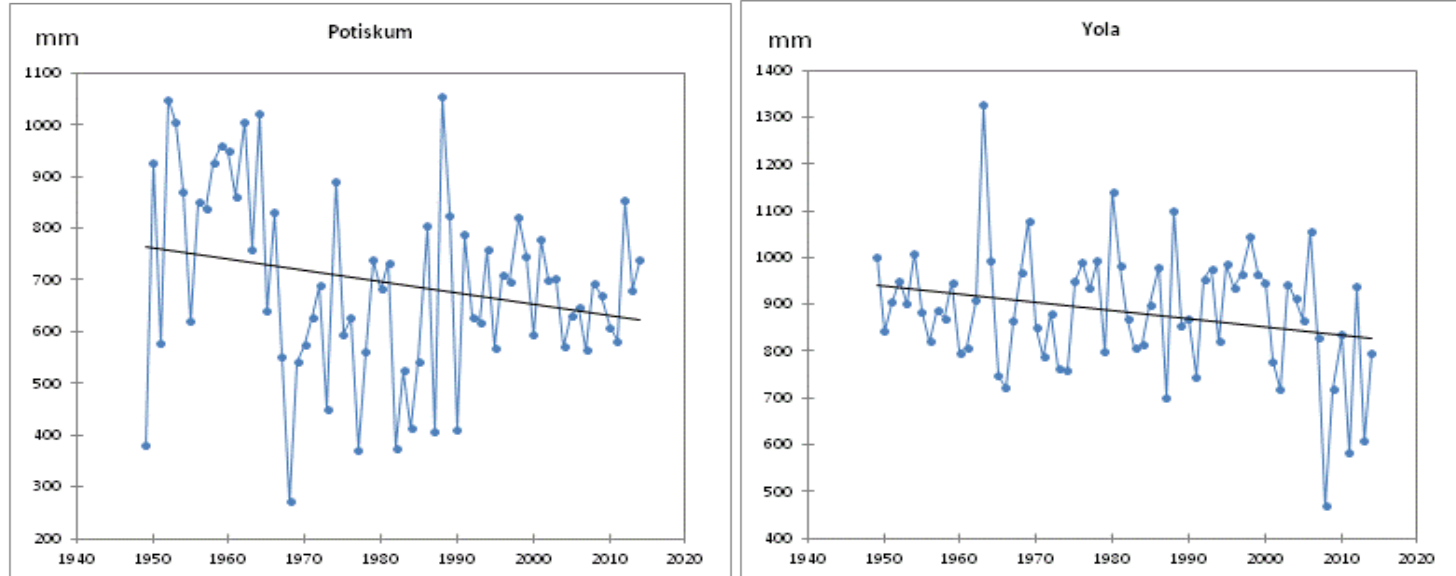

Figure 2: Inter-annual variability and trends of annual rainfall (mm) in northeastern parts of Nigeria, 1949-2014 All the trends are not linear as expressed by trend-to-noise-ratio values, which is due to high interannual variability of rainfall (figure 2).

Table 6: Annual rainfall trends/decade (mm), Mann-Kendall test for trend (Test Z) and trend-noise ratios in northeastern Nigeria, 1982-2014

\begin{tabular}{|l|l|l|l|l|l|}
\hline Station & Mean & Trend/decade & T/Noise & Test Z & Significance \\
\hline Bauchi & 1110 & 0.08 & 0.002 & 4.26 & $* * *$ \\
\hline Ibi & 1061 & 0.01 & 0.000 & 0.48 & \\
\hline Maiduguri & 578 & 0.05 & 0.002 & 2.96 & $* *$ \\
\hline Nguru & 418 & 0.06 & 0.003 & 3.33 & $* * *$ \\
\hline Potiskum & 658 & 0.02 & 0.001 & 0.95 & \\
\hline Yola & 857 & -0.03 & -0.001 & -1.38 & \\
\hline
\end{tabular}

Data source: NIMET, 2015.

See explanation in table 4

\section{Trends of Mean Annual Temperature}

Trends of mean annual temperature have been computed for a long-term period (1949-2014) and for two short-term periods (1949-1981) and (1982-2014).

\section{Long-term trends 1949-2014}

Table 7: Annual temperature trends $\left({ }^{\circ} \mathrm{C}\right)$, Mann-Kendall test for trend (Test $\left.\mathrm{Z}\right)$ and trend-noise ratios in northeastern Nigeria, 1949-2014

\begin{tabular}{|l|l|l|l|l|l|}
\hline Station & Mean & Trend/decade & T/Noise & Test Z & Significance \\
\hline Bauchi & 25.9 & 0.09 & 0.89 & 6.69 & $* * *$ \\
\hline Ibi & 27.6 & 0.04 & 0.78 & 3.49 & $* * *$ \\
\hline Maiduguri & 27.6 & 0.07 & 0.87 & 5.61 & $* * *$ \\
\hline Nguru & 27.6 & 0.05 & 0.56 & 4.26 & $* * *$ \\
\hline Potiskum & 26.9 & 0.07 & 0.70 & 5.39 & $* * *$ \\
\hline Yola & 28.3 & 0.08 & 0.87 & 6.29 & $* * *$ \\
\hline
\end{tabular}

Data source: NIMET, 2015.

See explanation in table 4

The result of the trend analysis showed that all the stations have positive trends. The trends ranged from $0.04{ }^{\circ} \mathrm{C} /$ decade at Ibi to $0.09{ }^{\circ} \mathrm{C} /$ decade at Bauchi (table 7). This finding is in line with the findings of IPCC (2014) which said that the trend of global temperature from 1951-2012 is 0.12 (0.08 to 0.14$){ }^{\circ} \mathrm{C}$ per decade. The test of significance revealed that all stations were significant at 0.001 levels of significance. All the trends were not linear as expressed by trend-to-noise-ratio values (figure 3 and 4).

\section{Short Term Trends 1949-1981}

The result of short-term trends (1949-1981) showed that trends existed in all the stations except Yola that had 0.00 trend ${ }^{\circ} \mathrm{C} /$ decade. The trends ranged between $0.03{ }^{\circ} \mathrm{C} /$ decade at Bauchi to 0.09 at Maiduguri and Nguru (table 8), Maiduguri and Nguru were highly significant at 0.001 while Bauchi and Ibi were weakly significant. None of the stations had a linear trend as all values for trend-to-noise fall below 1.96 due to interannual variability (figure 3 and 4). It is therefore clear that there was an increase in temperature over the period (1949-1981) in northeastern parts of Nigeria except in Yola where it was no trend. 
Table 8: Annual temperature trends $\left({ }^{\circ} \mathrm{C}\right)$, Mann-Kendall test for trend (Test $\left.\mathrm{Z}\right)$ and trend-noise ratios in northeastern Nigeria, 1949-1981

\begin{tabular}{|c|c|c|c|c|c|}
\hline Station & Mean & Trend/decade & T/Noise & Test Z & Significance \\
\hline Bauchi & 25.5 & 0.03 & 0.58 & 1.70 & + \\
\hline Ibi & 27.4 & 0.04 & 0.84 & 1.92 & + \\
\hline Maiduguri & 27.3 & 0.09 & 1.06 & 4.62 & $* * *$ \\
\hline Nguru & 27.3 & 0.09 & 1.06 & 4.83 & $* * *$ \\
\hline Potiskum & 26.5 & 0.05 & 0.70 & 2.51 & $*$ \\
\hline Yola & 27.9 & 0.00 & -0.01 & -0.02 & \\
\hline
\end{tabular}

Data source: NIMET, 2015.

See explanation in table 4

\section{Short Term Trends 1982-2014}

The short-term trends for the period 1982-2014 can be seen in the table 9, decreasing trends with values -0.02 and $-0.03{ }^{\circ} \mathrm{C} /$ decade prevailed at Ibi and Nguru, while increasing trends manifested at Bauchi, Potiskum and Yola. The values of the increasing trends ranged between $0.03{ }^{\circ} \mathrm{C} /$ decade at Potiskum to $0.05{ }^{\circ} \mathrm{C} / \mathrm{decade}$ at Bauchi and Yola, which is in line with IPCC (2014) which said that the trend of global temperature from 19982012 is $0.05{ }^{\circ} \mathrm{C}$ per decade. Trends were not linear as expressed by trend-to-noise-ratio values, resulting from high inter-annual temperature variability at all the stations (Figure 3 and 4).

Table 9: Annual temperature trends $\left({ }^{\circ} \mathrm{C}\right)$, Mann-Kendall test for trend (Test $\left.\mathrm{Z}\right)$ and trend-noise ratios in northeastern Nigeria, 1982-2014

\begin{tabular}{|l|l|l|l|l|l|}
\hline Station & Mean & Trend/decade & T/Noise & Test Z & Significance \\
\hline Bauchi & 26.4 & 0.05 & 0.65 & 2.62 & $* *$ \\
\hline Ibi & 27.8 & -0.02 & -0.38 & -1.21 & \\
\hline Maiduguri & 27.8 & 0.00 & -0.05 & -0.12 & \\
\hline Nguru & 27.9 & -0.03 & -0.32 & -1.53 & \\
\hline Potiskum & 27.3 & 0.03 & 0.30 & 1.55 & \\
\hline Yola & 28.8 & 0.05 & 0.70 & 2.62 & $* *$ \\
\hline
\end{tabular}

Data source: NIMET, 2015.

See explanation in table 4
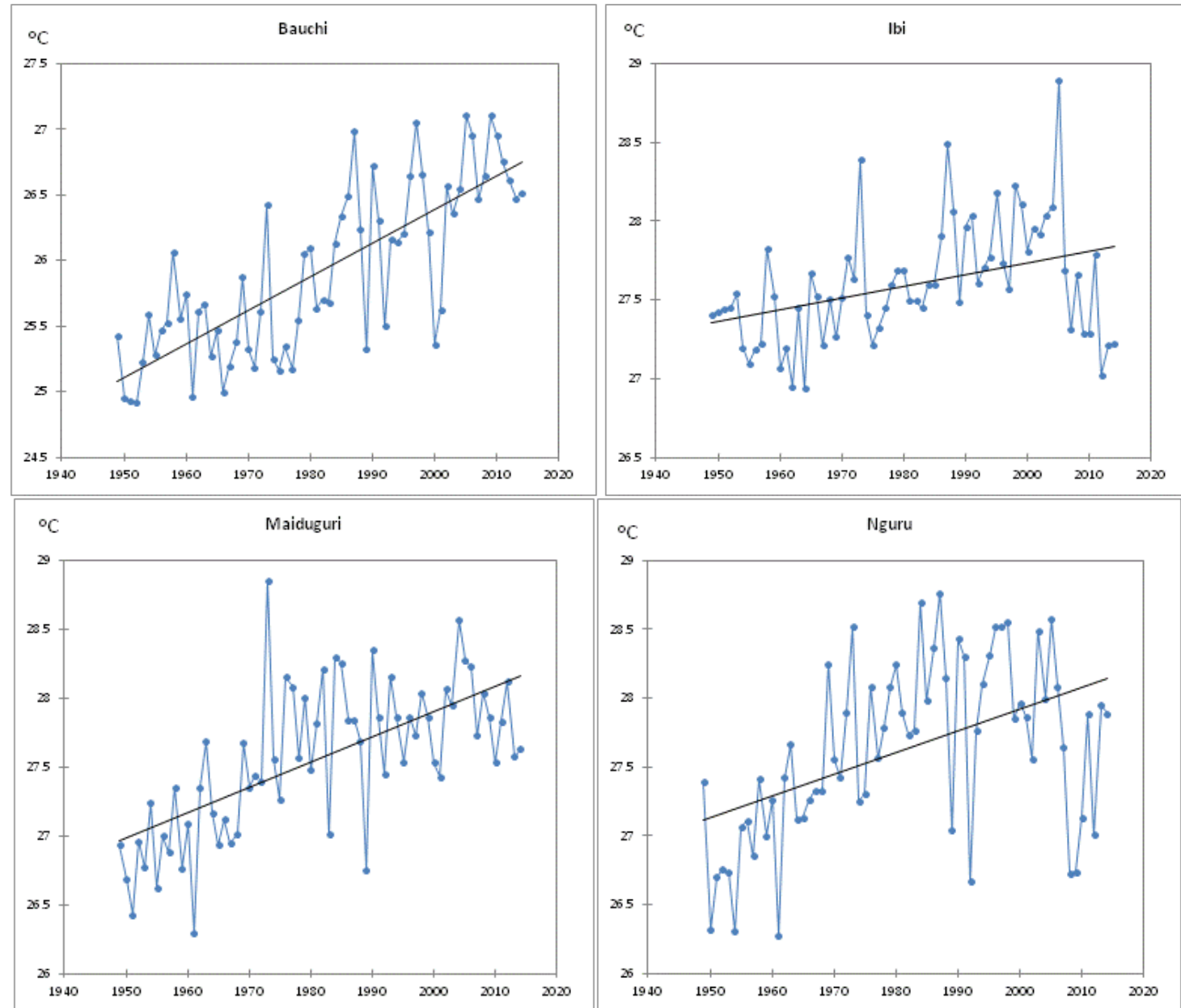

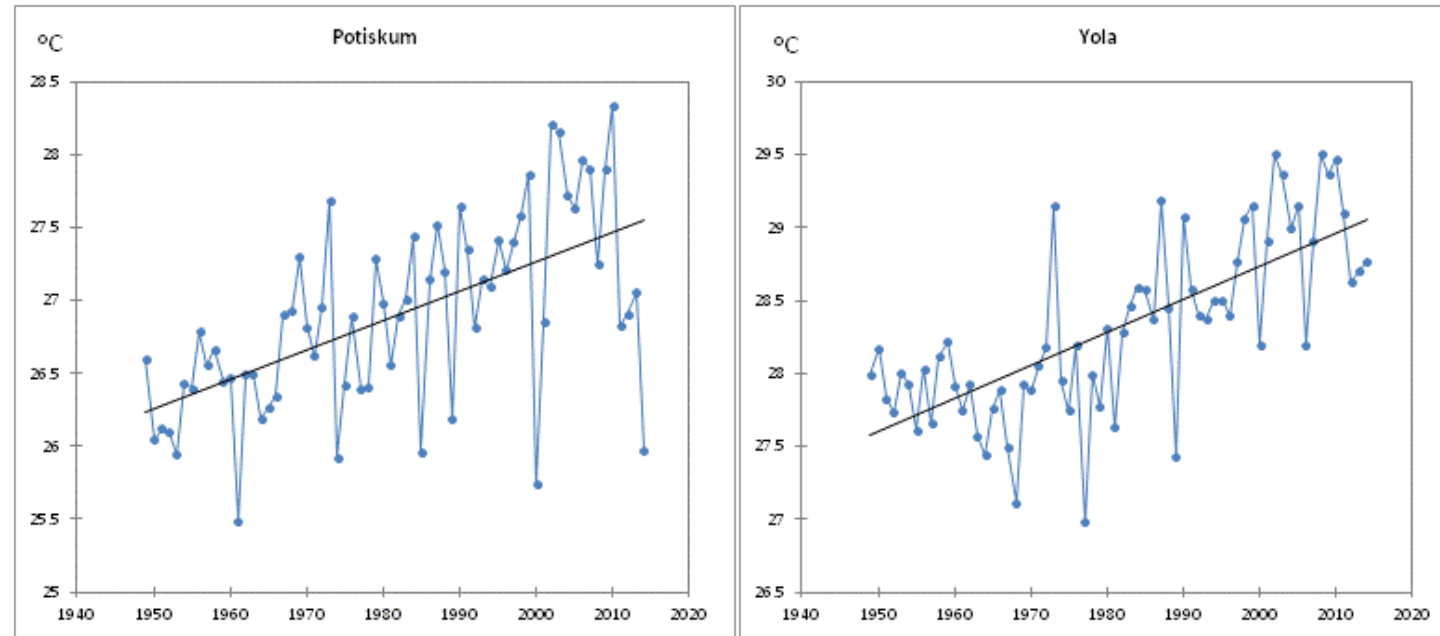

Figure 3: Inter-annual variability and trends of annual temperature in northeastern Nigeria, 1949-2014 (Data source: NIMET 2015).

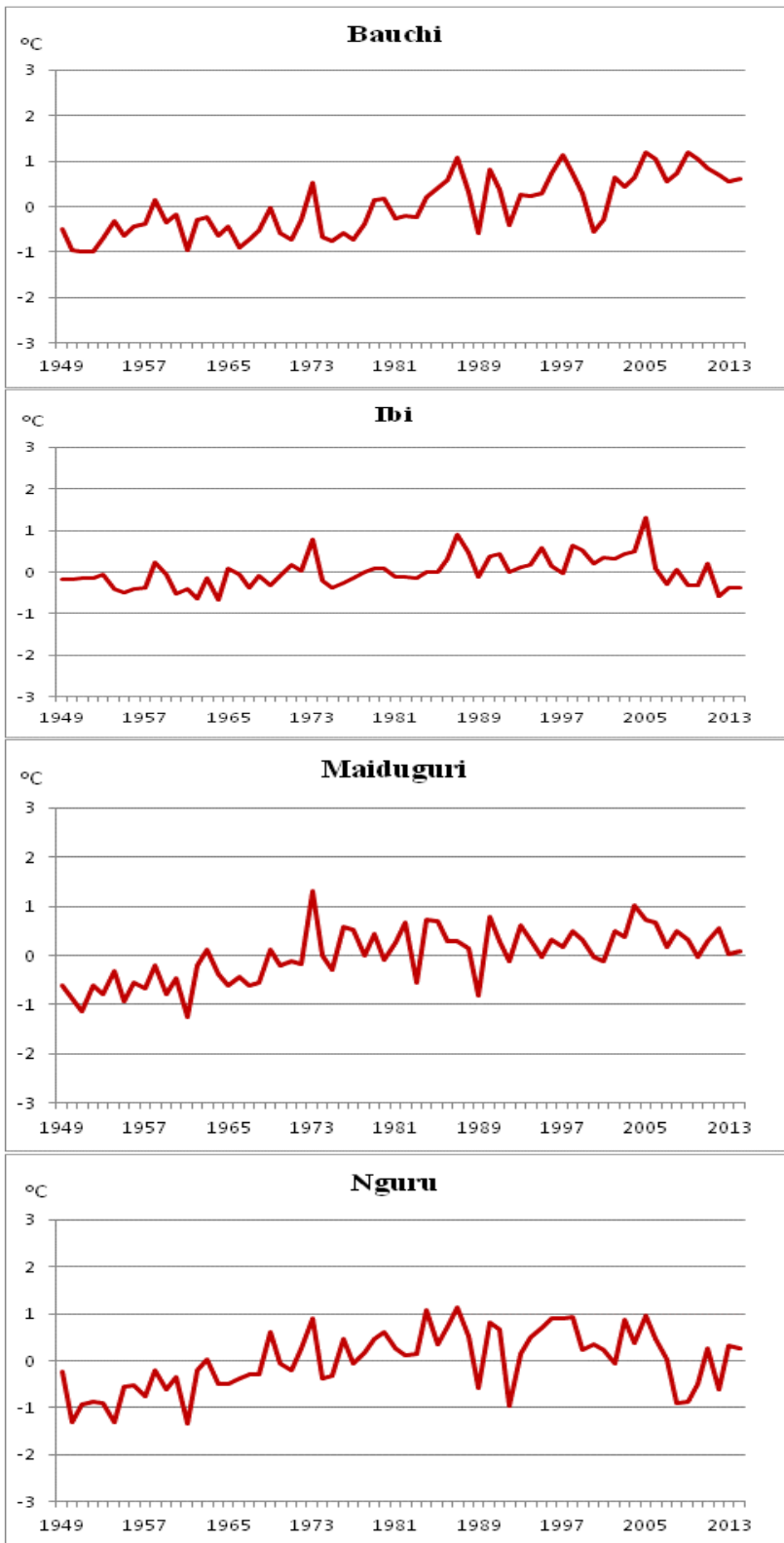




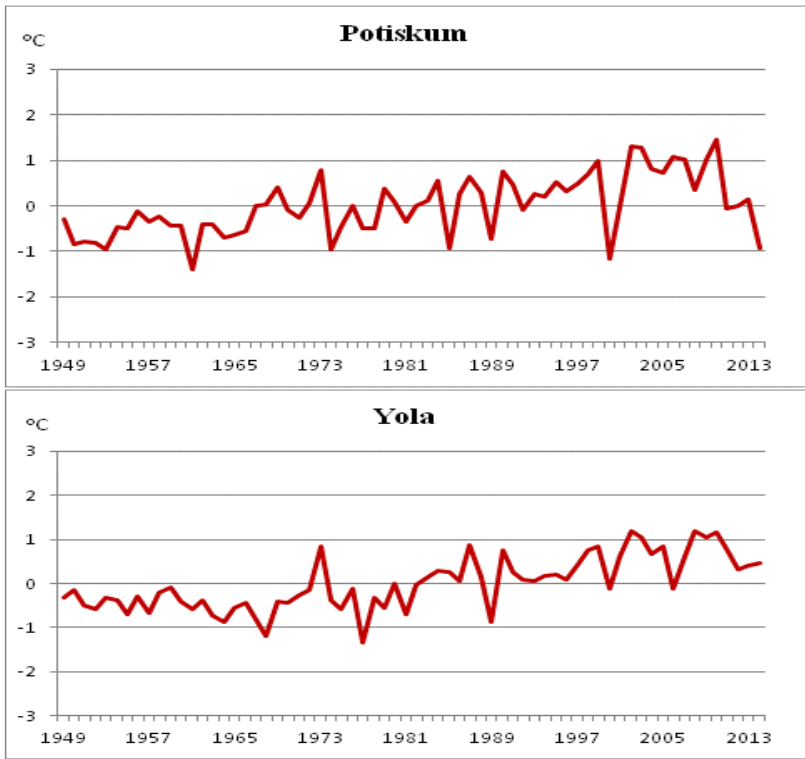

Figure 4: Anomalies of mean annual temperatures in northeastern Nigeria, 1949-2014

Data source: NIMET, 2015

\section{Northeastern Nigeria and global climate change}

The result of trend analysis shows a strong evidence of increased temperature in northeastern Nigeria. According to (IPCC, 2013) the global trends over the past 15 years $1998-2012$ is $0.05(-0.05$ to 0.15$){ }^{\circ} \mathrm{C}$ per decade, while for the period 1951-2012 the trend is $0.12(0.08$ to 0.14$){ }^{\circ} \mathrm{C}$ per decade. This is in line with the findings of this research which showed a warming over these periods (1949-2014; 0.07[0.04 to 0.09] ${ }^{\circ} \mathrm{C}$ per decade); (1949-1981; 0.05[0.0 to 0.09] ${ }^{\circ} \mathrm{C}$ per decade) and (1982- 2014; 0.02[-0.02 to 0.05] ${ }^{\circ} \mathrm{C}$ per decade). The result of this study is also consistent with similar studies that observed an increase in temperature for the area in recent years (Kasim and Bose, 2015; Farauta et al 2011; Odjugo, 2010; Anuforom, 2010).

The increased atmospheric moisture content associated with warming might be expected to lead to increased global rainfall (IPCC, 2007). Over the $20^{\text {th }}$ century global annual precipitation showed an upward trend of approximately $1.1 \mathrm{~mm} /$ decade. Nevertheless, the record is characterized by large inter-decadal variability, and since the 1950 global annual land mean precipitation shows a non-significant decline. This study found a decrease in rainfall over long term period (1949-2014) which is in line with studies by (Oguntunde $e t$ al., 2006; L'Hóte et al., 2002; Nicholson et al., 2000) which have shown that Africa has been drier in the last few decades.

\section{Conclusion}

From the present study, it is safe to conclude that there is a decreasing trend in annual rainfall total over a long period (1949-2014) and short period (1949-1981) in northeastern Nigeria. The exception is for the period (1982-2014) which has an increase in trend. The temperature on the other hand, showed an increasing trend in all the 3 periods especially the long-term period (1949-2014) that shows a very high level of significance. These findings are in line with the global temperature trend of $0.05{ }^{\circ} \mathrm{C}$ per decade for the period (1951-2012), IPCC (2014). The result provides enough evidence of climate change in the region, which could affect socio-economic developments.

The following recommendations were made:

- Alternative means of fuel should be provided so as to reduce over dependence on fuel wood.

- Qualitative climatic data should be made available and accessible to sectors that are sensitive to climate such as agriculture and water resources.

- Afforestation should be encouraged while deforestation should be discouraged.

\section{References}

[1]. Abaje, I. B., Ati O. F., and Iguisi, E.O., (2012): Recent trends and fluctuations of annual rainfall in the Sudan-Sahelian ecological zone of Nigeria: Risks and opportunities. Journal of Sustainable Society, Vol. 1(2), pp. 44-51.

[2]. Abdussalam, A.F., (2015): Changes in Indices of Daily Temperature and Precipitation Extremes in Northwest Nigeria. Science World Journal Vol 10 (No 2)

[3]. Akinsanola A. A., Ogunjobi, K. O., (2014): Analysis of rainfall and temperature variability over Nigeria. Glob J Hum Soc Sc Res $14: 3$ 
[4]. Anuforom A. C., (2010): Demonstration and assessment of climate change in Nigeria and development of adaptation strategies in the key socio-economic sectors: meteorological approach. In a paper presented at the National Stakeholders Workshop on Developing National Adaptation Strategies and Plan of Action for Nigeria, held on 22nd, March. NIMET. Abuja, Nigeria.

[5]. Biasutti, M., \& Giannini, A., (2006): A robust Sahel drying in response to late 20th century forcing. Geophys. Res. Letters, 11, L 11 706.

[6]. Bose, M. M., Abdullah, A. M., Kasim, I., Harun, R., Mande, K. H., Abdullahi, A. C., (2015): Rainfall Trend Detection in Northern Nigeria over the Period of 1970-2012. Journal of Environment and Earth Science Vol.5, No.2.

[7]. Bose, M. M., Abdullah, A. M., R, H., Jamalani, M.A., R.E, E., \& M., F. (2014): Perception of and adaptation to climate change by farmers in the semi - arid zone of North - eastern Nigeria. IOSR Journal of Environmental Science, Toxicology and Food Technology.

[8]. Burroughs, W. J., (2007): Climate Change: A Multidisciplinary Approach, Second Edition. Cambridge University Press. ISBN: 9780521690331.

[9]. Domrös, M., (1996): Rainfall variability over Sri Lanka. In: Yash P. A., Suloclana G., and Govind B. P. (Eds.), 1996: Climate variability and agriculture, Narosa Publishing House, New Delhi: 163-179.

[10]. El-Tantawi, A. M. M., (2005): Climate Change in Libya and Desertification of Jifara Plain Using Geographical Information System and Remote Sensing Techniques. Unpublished PhD thesis Johannes Gutenberg-Universität in Mainz, Germany.

[11]. Ewona, I. O., and Udo, S. O., (2008): Trend studies of some meteorological parameters in Calabar. Nigerian Journal of Physics, 20(2), 283-289

[12]. Farauta B. K., Egbale, C. L., Idrissa, Y. C., Agu, V. C., (2011): Climate change and adaptation measures in northern Nigeria: Empherical Situation and Policy Implications (No. 62). Nairobi, Kenya: African Technology Policy Studies Network.

[13]. Houghton, J. T., Ding, Y., Griggs, D. J., Noguer, M., Linden, P. J., Dai, X., Maskell, K. and Johnson C. A., (eds.), (2001): Climate Change: the Scientific Basis, Working Group I, Third Assessment Report, Intergovernmental Panel on Climate Change, UNEP and WMO

[14]. IPCC (2008): Climate change and water. Technical paper of the Intergovernmental Panel on Climate Change [Bates, B.C., Kundzew, Z. W.,Wu, S., and Palutikof, J.P.(Eds.)], IPCC Secretariat, Geneva. 210 p.

[15]. IPCC (2013): Summary for Policymakers. In: Climate Change 2013: The Physical Science Basis. Contribution of Working Group I Contribution to the Fifth Assessment Report of the Intergovernmental Panel on Climate Change.

[16]. IPCC (2014): Climate Change 2014: Synthesis Report. Contribution of Working Groups I, II and III to the Fifth Assessment Report of the Intergovernmental Panel on Climate Change [Core Writing Team, R.K. Pachauri and L.A. Meyer (eds.)]. IPCC, Geneva, Switzerland, $151 \mathrm{pp}$.

[17]. Kasim, I., and Bose, M. M., (2015): Rising Temperature: Evidence of Global Warming in Northern Nigeria Journal of Environment and Earth Science Vol.5, No.22.

[18]. L'Hóte, Y., Mahe, G., Some, B., and Triboulet, J. P., (2002): Analysis of a Sahelian annual rainfall index from 1896 to 2000 ; the drought continues. Hydrological Science Journal, 48(3), 489-496.

[19]. Nicholson, S. E., Some, B., \& Kone, B., (2000): An analysis of recent rainfall conditions in West Africa, including the rainy seasons of the 1997 El Niño and the 1998 La Niña years. Journal of Climate, 13(14), 2628-2640.

[20]. Odjugo, P. A., (2010): General overview of climate change impacts in Nigeria. Journal of Human Ecology, 29(1), 47-55.

[21]. Oguntunde P. G., Friesen, J., van de Giesen N., and Savenije, H.H.G., (2006): Hydro-climatology of the Volta River Basin in West Africa: Trends and variability from 1901 to 2002. Physics and Chemistry of the Earth, 31, 1180-1188.

[22]. Olofintoye, O. O., and Sule, B. F, (2010): Impact of global warming on the rainfall and temperature in the Niger Delta of Nigeria. USEP Journal of Research Information and Civil Engineering, 7(2), 33 - 48.

[23]. Schönwiese, C., (1992): Praktische Statistik für Meteorologen und Geowissenschaftler, 2. verbesserte Auflage, Gebrüder Borntraeger, Berlin and Stuttgart.

[24]. Yue, S., and Hashino, M., (2003): Long term trends of annual and monthly precipitation in Japan. J. American Water Resources Association, 39(3): $587-596$ 